\title{
Labour migration to the UK from Eastern partnership countries
}

\author{
Ken Clark ${ }^{1 *}$ and Stephen Drinkwater ${ }^{2}$
}

\author{
* Correspondence: \\ ken.clark@manchester.ac.uk \\ ${ }^{1}$ IZA \& University of Manchester, \\ Manchester, UK \\ Full list of author information is \\ available at the end of the article
}

\begin{abstract}
Stocks and flows of migrant workers from EaP countries in the UK are relatively small, and flows have declined recently following changes to UK immigration policy and the onset of recession. The demographic profile of migrants from EaP countries is similar to that of EUA8 migrants but employment rates have been much lower. A large proportion of migrants to the UK from EaP countries are highly educated but this has not led to such high levels of occupational attainment as groups such as EU14 migrants. Despite the potential for increased migration to fill skill gaps, immigration policies and attitudes to immigrants are likely to restrict future flows.
\end{abstract}

JEL Classifications: J61; F22.

Keywords: Migration; Eastern partnership countries; United Kingdom; Labour market

\section{Introduction}

The United Kingdom (UK) has a long history of receiving large numbers of migrant workers. In particular, successive cohorts of immigrants from former Commonwealth colonies, especially in the West Indies and the Indian sub-continent, started arriving at the end of the 1940s (Hatton and Wheatley Price 2005). Many of these migrant workers took up positions in sectors experiencing labour shortages, such as transport, the National Health Service and other public services, and self-employment was also an important form of activity for some of the migrant groups (Clark and Drinkwater 1998). Over the last decade, however, the UK has also become one of the main destination countries for immigrants from various parts of Europe. For example, data on National Insurance Numbers issued to overseas nationals (NINos) indicate that there was a five-fold increase in the number of "new" immigrant workers arriving in the UK from European countries between 2002 and 2007, rising from around 103,000 to over $500,000^{1}$. As a result, the percentage of NINo registrations made by Europeans almost doubled, rising from 33 per cent to 63 per cent over this period ${ }^{2}$. Much of this increase can be explained by the migration that followed the enlargement of the European Union in May 2004, since the UK was one of only three member states at the time to open their border to migrant workers from the new member states in Central and Eastern Europe $^{3}$. Although the number of NINo registrations made by Europeans has fallen since the start of the recession, it stood at 342,000 in 2010 and continued to account for over a half of the total NINo registrations made in the UK that year. 
In addition to the migration flows that have followed enlargement of the European Union, there have also been important changes over the last decade in policy in the UK towards immigrants from outside the European Economic Area (EEA). In particular, the overall thrust of immigration policy in the UK since 2005 has been to restrict entry by non-EEA workers to skilled occupations. The main change was the introduction of the Points Based System (PBS), which began in 2008 to regulate inflows of immigrant workers from outside the EEA. The PBS consolidated in excess of 80 work and study routes into the UK, which included the Highly Skilled Migrant Programme and Work Permits, into five main tiers and replaced the previous system of immigration (Devitt 2012). These five tiers relate to highly skilled migrants, medium and highly skilled migrants with a job offer, quota based low-skilled schemes to fill temporary labour shortages, students and youth mobility and temporary workers.

Changes have also occurred to two low-skilled schemes, which lie outside the PBS. These are the Seasonal Agricultural Workers Scheme (SAWS) and the Sector Based Schemes (SBS). From 2008 these were targeted exclusively at Bulgarian and Romanian nationals allowing a quota of around 20,000 each year to enter the UK for up to six months to work in the agricultural sector. From 2014 the SAWS and SBS were closed to all workers. However, prior to the accession of Bulgaria and Romania to the European Union in 2007, these schemes had been open to migrants from other countries and large numbers of Ukrainians, Belarusians and Moldovans were employed on them in the mid-2000 s. . For example, Salt (2009) reports that Ukrainians accounted for 33 per cent of the 16,127 workers on the SAWS and 38 per cent of the 3,586 workers on the SBS in 2006. In 2004, there were 2,258 workers from Belarus registered on the SAWS and more than 1,000 Moldovans were on the same scheme in each year between 2005 and 2007. Therefore, the changes in immigration policy that have occurred in the UK over the last decade are of particular importance to Eastern Partnership $(\mathrm{EaP})$ countries because potential migrant workers to the UK from these countries are not able to benefit from the freedom of movement enjoyed by individuals from the European Union, including from the member states that joined in 2004 and neither can younger migrants from EaP countries now enter the UK on the SAWS or SBS. In addition to impacting on the size of migration flows from EaP countries, these policy changes are likely to have had an effect on the composition of migrant workers. For example, migration flows from EaP countries are likely to have become less dominated by the youngest age groups and biased more towards women and highly educated individuals.

The changes in migration flows and in immigration policy should also be considered with reference to the UK's economy, which was in a healthy position from 2000 up until 2007. This period produced average growth rates of 2.75 per cent per annum and annual unemployment rates of around 5 per cent. However, since the start of the global financial crisis in late 2007, the economy has deteriorated considerably. The UK was officially in recession in 2008 and 2009, with Gross Domestic Product (GDP) falling by around 6 per cent (Gregg and Wadsworth 2010). As a result of the poor state of the economy, unemployment has increased and has hovered around 8 per cent in recent years. Very high levels of youth unemployment are a major concern (Blanchflower and Bell 2010), with the unemployment rate for 16 and 17 year olds at almost 40 per cent, and that for 18-24 year olds at 20 per cent. Given that immigrants are thought to 
compete with younger native-born workers for jobs and that employment levels amongst immigrants have continued to rise - while falling for the native-born (ONS 2012) -then public attitudes towards immigration in the UK tend to be quite negative. For example, Blinder (2011) reports evidence from cross-national survey data (Transatlantic Trends 2010) to suggest that people from the UK have more negative views towards immigrants than people from other Western countries. In particular, the percentage of respondents reporting that "there are too many immigrants" and "immigration is more a problem than an opportunity" was higher in the UK than it was in France, Germany, Italy, Spain and the United States. Furthermore, there is now a consistent opposition to immigration across all major political parties in the UK and the coalition government is committed to reducing net migration from hundreds of thousands to "tens of thousands".

In this paper we describe the migration flows and labour market outcomes of migrants from EaP countries and compare them with other groups of migrants and established workers. Both stocks and flows of EaP migrants are small relative to other immigrant groups and flows are found to be responsive to GDP growth, but have been mainly driven by changes in immigration policy. We find that while EaP migrants exhibit some similarities to the EUA8 migrant group, there are some important differences too, particularly in terms of human capital and employment outcomes. We note that EaP countries have high stocks of human capital in STEM-related subjects which are in demand in the UK, however in the absence of significant changes in immigration policy, future flows of EaP workers to the UK are predicted to remain small in magnitude.

The paper is organised in the following manner. The next section contains a discussion of recent inflows of migrant workers from EaP countries to the UK, along with some information on the stocks of migrants from these countries. Subsequently the focus is on the demographic characteristics of migrants from EaP countries, mainly using the Labour Force Survey (LFS). The use of this dataset also enables similar information to be provided on comparison groups of migrants in the UK and the paper moves on to examine the labour market characteristics of the same groups that are analysed in the preceding section. Some concluding comments can then be found in the final section, especially in relation to policy implications.

\section{Flows of migrants from EaP Countries to the UK and migrant stocks}

Data on inflows of migrants from EaP countries are obtained from administrative data published by the Home Office. The data identify passengers given leave to enter between 2004 and 2010 for four different reasons: employment, study, family and other. The main focus is on individuals given leave to enter the UK for employment purposes but aggregate information on all passengers arriving from the six EaP countries is reported in Additional file 1: Table S1. The table suggests that although the total number of passengers to the UK from EaP countries has increased by over a third between 2004 and 2010, they only account for a very small proportion of total passengers to the UK. In 2004, only 0.7 per cent of passengers of all nationalities came from EaP countries, rising to 1.0 per cent in 2010. Around 60 per cent of EaP passengers in each year came from the Ukraine, with around 15 per cent from Belarus and around 9 per cent from Azerbaijan. 
The breakdown in the number of passengers into its four constituent categories is shown in Additional file 1: Table S2 for EaP countries and for all nationalities. However, the vast majority of passengers to the UK are in the "Other" category. This category mainly consists of "visitors", and includes both ordinary and business visitors, as well as people returning from a temporary absence abroad and passengers in transit. Following the "Other" category, employment is the next most important category for passengers given leave to enter the UK for individuals from EaP countries. However, the numbers entering via this route have fallen for this group of countries, especially since 2007. In contrast, the number of people entering the UK via the study route has increased by over 1,000 since 2005 but EaP countries still only account for less than 1 per cent of the total number of student visas issued. The family category is the smallest, with only a total of 435 individuals from EaP countries entering the UK on this type of visa in 2010.

Figure 1 shows the trend in the numbers of migrants from EaP countries entering the UK through the employment route between 2004 and 2010. Ukraine is measured on the left-hand vertical axis with the other countries measured on the right. The large falls in the volume of migrant workers arriving from the Ukraine is particularly noticeable after 2006. The change between 2007 and 2008 was especially large, since employment visas issued to Ukrainians fell from over 5,000 to just above 1,000. Workers given leave to enter from Belarus and Moldova also showed a sharp decline after 2007. Changes in the number of employment visas issued to Armenian, Azerbaijani and Georgian nationals are much smaller because the levels at the start of the period were far lower. Additional file 1: Table S2 does, however, show these changes and indicates that the number of migrants from Armenia and Georgia entering the UK via the employment route fell by more than half between 2004 and 2010, but there has been an increase amongst Azerbaijani migrants. For example, 100 employment visas were issued to Azerbaijani migrants in 2005 but this rose to 220 in 2009 before falling back to 195 in 2010.

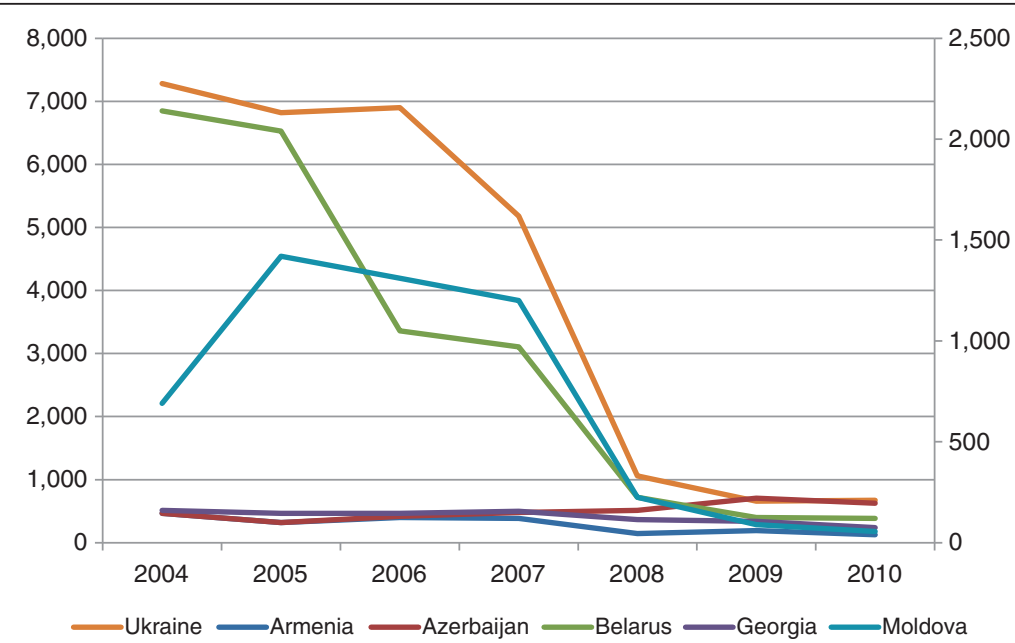

Figure 1 Individuals given leave to enter the UK via the employment route from EaP countries, 2004-10. Notes: Data are sourced from the Home Office. Ukraine is measured on the left hand vertical axis while the other countries are measured on the right hand axis. 
The changes in the number of people entering through the employment route can be further investigated by splitting the work category into pre-and post-PBS periods and also into different types of work categories. Table 1 reports information in the pre-PBS period (2004-2007) and shows that the number of work permits issued in 2007 declined sharply, especially to Ukrainians since only around half the amount were issued in this year compared to 2005. However, there is also a fall of around 1,000 in the number of Ukrainians in the other category in 2007, which is the result of the changes in terms of eligibility made to the SAWS and SBS. Large falls in this category are also observed for Belarusians, with a decline of over 1,000 (63 per cent) in 2007 compared to 2004. In contrast, the number of Moldovans in the "other" category remained fairly constant between 2005 and 2007, following the large rise seen between 2004 and $2005^{5}$.

Information on EaP migrant workers entering the UK in the PBS period (2008-2010) is shown in Table 2. This splits migrants entering via the employment route into three broad groups: the PBS categories, the pre-PBS categories and dependents (which combines those entering both through the pre-PBS and PBS routes). Employment entrants from EaP countries continued to arrive in the UK through pre-PBS categories in 2008, although the numbers were far lower than in the pre-PBS period since only 1,545 migrants from EaP countries entered in 2008, compared to more than 9,000 in 2007 -as indicated in Table 1. Only 30 migrants from EaP countries came through the PBS routes in 2008 but this rose to 815 in 2010, with Ukrainians accounting for over 60 per cent of this figure.

Flow data on migrants to the UK are also available from the NINo database, maintained by the Department of Work and Pensions. This again is an administrative database which contains information on overseas nationals registering for a national insurance number in the UK. The majority of the individuals in this database have already taken up or are about to take up employment in the UK, but it does also contain people claiming certain benefits. This should, therefore, represent a relatively accurate record of new migrant workers entering the UK for the first time (Drinkwater et al. 2010). The data are available from the start of 2002 up until the fourth quarter of 2013, which is the latest information available at the time of writing. The information can be split by calendar or financial year of registration. Figure 2 provides information

Table 1 Employment entrants from EaP countries to the UK in the Pre-PBS period by category

\begin{tabular}{|c|c|c|c|c|c|c|c|c|c|c|c|c|}
\hline & \multicolumn{4}{|c|}{ Work permits } & \multicolumn{4}{|c|}{ Other } & \multicolumn{4}{|c|}{ Employment: dependents } \\
\hline & 2004 & 2005 & 2006 & 2007 & 2004 & 2005 & 2006 & 2007 & 2004 & 2005 & 2006 & 2007 \\
\hline Armenia & 120 & 75 & 40 & 55 & 10 & 25 & 75 & 55 & 15 & 5 & 10 & 10 \\
\hline Azerbaijan & 80 & 60 & 70 & 70 & 25 & 15 & 35 & 50 & 40 & 25 & 25 & 30 \\
\hline Belarus & 400 & 535 & 185 & 295 & 1,700 & 1,450 & 815 & 625 & 40 & 50 & 50 & 50 \\
\hline Georgia & 70 & 35 & 40 & 35 & 85 & 100 & 100 & 95 & 5 & 10 & 5 & 20 \\
\hline Moldova & 415 & 545 & 375 & 260 & 265 & 845 & 910 & 900 & 10 & 20 & 25 & 35 \\
\hline Ukraine & 2,100 & 2,120 & 1,950 & 1,150 & 5,040 & 4,505 & 4,740 & 3,820 & 140 & 200 & 215 & 210 \\
\hline All EaP countries & 3,185 & 3,370 & 2,660 & 1,865 & 7,125 & 6,940 & 6,675 & 5,545 & 250 & 310 & 330 & 355 \\
\hline
\end{tabular}

Source: Home Office.

Notes: Cells with fewer than 1,000 observations have been rounded to the nearest 5 and numbers greater than 1,000 rounded to three significant figures. Therefore, totals may not add due to rounding. Other work categories include persons entering the UK in the following pre-PBS categories: ministers of religion; postgraduate doctors or dentists; working holidaymakers; seasonal agricultural workers; diplomats, consular officers or persons in foreign and Commonwealth government missions; nurses-supervised practice; investors; Highly Skilled Migrant Programme; and au pairs. 
Table 2 Employment entrants from EaP countries to the UK in the PBS period by category

\begin{tabular}{|c|c|c|c|c|c|c|c|c|c|}
\hline & \multicolumn{3}{|c|}{ PBS categories } & \multicolumn{3}{|c|}{ Pre-PBS and Non-PBS categories } & \multicolumn{3}{|c|}{$\begin{array}{c}\text { Dependents: employment } \\
\text { and PBS } \\
\end{array}$} \\
\hline & 2008 & 2009 & 2010 & 2008 & 2009 & 2010 & 2008 & 2009 & 2010 \\
\hline Armenia & * & 20 & 30 & 35 & 35 & * & 15 & 10 & 10 \\
\hline Azerbaijan & 5 & 80 & 125 & 115 & 90 & 40 & 40 & 50 & 25 \\
\hline Belarus & 5 & 60 & 75 & 180 & 40 & 15 & 40 & 30 & 30 \\
\hline Georgia & * & 55 & 40 & 90 & 35 & 30 & 20 & 15 & 5 \\
\hline Moldova & 0 & 25 & 35 & 215 & 50 & 15 & 10 & 20 & 0 \\
\hline Ukraine & 20 & 325 & 510 & 910 & 205 & 55 & 135 & 125 & 110 \\
\hline All EaP countries & 30 & 565 & 815 & 1,545 & 455 & 155 & 260 & 250 & 180 \\
\hline
\end{tabular}

Source: Home Office.

Notes: *denotes that the cell contains 1 or 2 observations. See also notes to Table 1.

on overall flows from EaP countries. Note that in this figure Ukrainian registrations are measured on the left hand axis while the other countries are measured on the right hand axis. This figure confirms the trends shown in Figure 1, but the reductions are not as sharp. For example, the number of NINo registrations by Ukrainians falls from an (annualised) average of around 2,000 in 2004-2007 to around 1,200 in 2008-2010.

We can summarise the impacts of the economic cycle and the policy changes on flows of EaP migrant workers by estimating a regression model where the dependent variable is the number of quarterly NINo registrations for individuals from EaP countries. The independent variables include quarterly UK GDP growth lagged by one quarter and a dummy variable which reflects the introduction of the PBS in the third quarter of 2008. There is also a seasonal spike in registrations in the first quarter of the year, for administrative reasons, so we also include a dummy for Q1. The results are summarised in Table 3 for three samples: all EaP NINo registrants in columns (1) and (2) and then separately for Ukrainians and non-Ukrainians in the remaining columns. The results suggest that lagged growth, together with the quarterly dummy, explains up

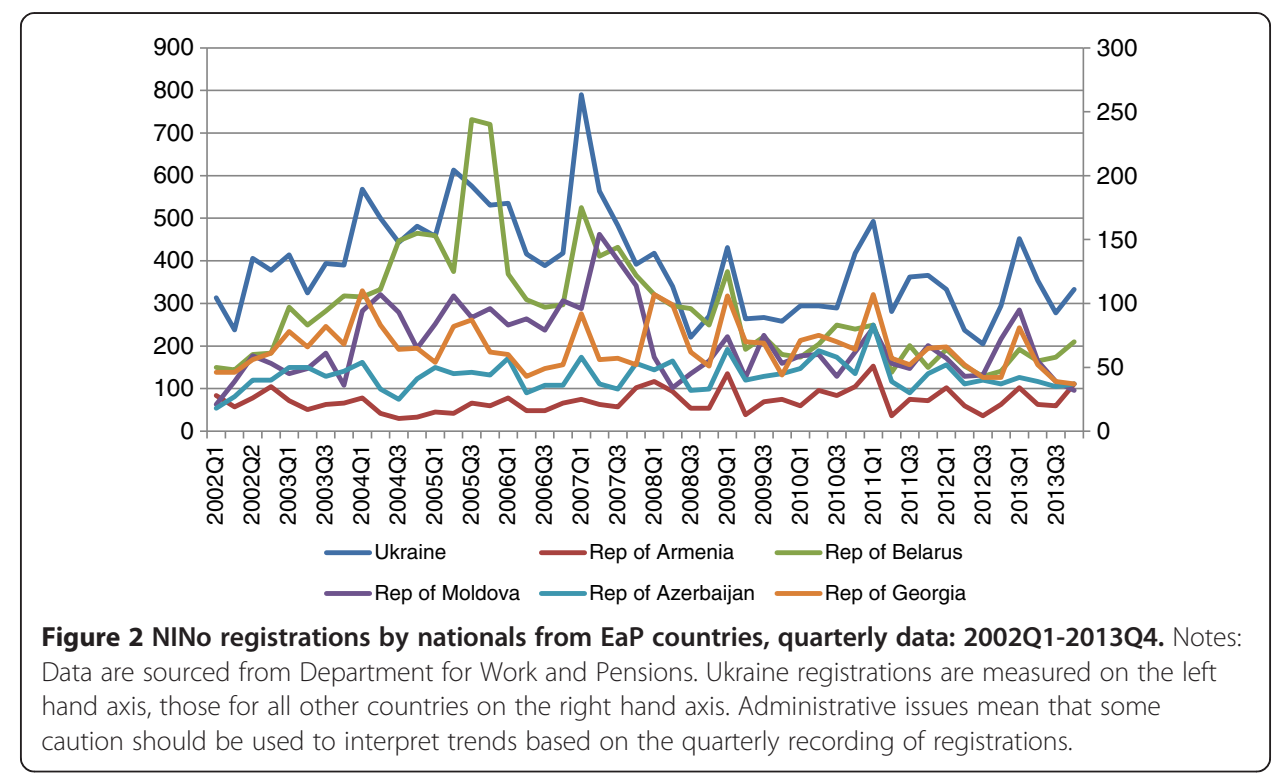


Table 3 Regression model of EaP NINo registrations 2002Q1-2013Q4

\begin{tabular}{lcccccc}
\hline & $\mathbf{( 1 )}$ & $\mathbf{( 2 )}$ & $\mathbf{( 3 )}$ & $\mathbf{( 4 )}$ & $\mathbf{( 5 )}$ & $\mathbf{( 6 )}$ \\
& All EaP & All EaP & Ukraine & Ukraine & Non-Ukraine & Non-Ukraine \\
\hline Lagged growth & $85.06^{* * *}$ & $48.32^{*}$ & $61.20^{* * *}$ & $39.54^{* *}$ & $23.86^{*}$ & 8.784 \\
& $(29.37)$ & $(28.08)$ & $(18.17)$ & $(17.61)$ & $(12.71)$ & $(12.33)$ \\
Quarter 1 & $179.8^{* * *}$ & $181.6^{* * *}$ & $110.2^{* * *}$ & $111.3^{* * *}$ & $69.59^{* *}$ & $70.33^{* * *}$ \\
& $(56.33)$ & $(50.10)$ & $(34.86)$ & $(31.42)$ & $(24.39)$ & $(22.00)$ \\
Policy & & $-163.9^{* * *}$ & & $-96.60^{* * *}$ & & $-67.25^{* * *}$ \\
& & $(46.07)$ & & $(28.89)$ & & $(20.24)$ \\
Constant & $618.7^{* * *}$ & $701.6^{* * *}$ & $344.2^{* * *}$ & $393.1^{* * *}$ & $274.5^{* * *}$ & $308.5^{* * *}$ \\
& $(29.61)$ & $(35.16)$ & $(18.32)$ & $(22.05)$ & $(12.82)$ & $(15.44)$ \\
Observations & 47 & 47 & 47 & 47 & 47 & 47 \\
R-squared & 0.285 & 0.447 & 0.313 & 0.455 & 0.200 & 0.364 \\
\hline
\end{tabular}

Note: Standard errors in parentheses. ${ }^{* * *} p<0.01,{ }^{* *} p<0.05,{ }^{*} p<0.1$.

to $30 \%$ of Ukrainian registrations and up to $20 \%$ of non-Ukrainian registrations. Adding in the policy dummy increases the goodness of fit and attenuates the effect of growth somewhat, however the lagged growth term is still positive and, for the Ukrainians, statistically significant. The policy changes associated with the introduction of PBS reduced registrations by around 100 Ukrainians and 70 non-Ukrainians per quarter. Conditional on immigration policy, a 1 percentage point increase in the growth rate of the UK economy is estimated to increase the number of Ukrainian registrations by around 40 per quarter with an equivalent figure of around 10 for non-Ukrainians. Thus policy changes around the time of the introduction of the PBS appear to be an important factor in explaining the falling numbers of workers arriving in the UK from $\mathrm{EaP}$ countries. This analysis is consistent with the results of Hatton (2005) where changes in immigration policy in the UK and in source countries explain the bulk of changes in net migration to the UK over the period between the mid-1970s and 2000.

The NINo database also indicates that the total number of registrations from EaP countries peaked in 2007 at 3,860, which was the same year as total NINo registrations reached a peak in the UK. However in that year, EaP nationals accounted for less than 0.5 per cent of total NINo registrations in the UK. This percentage was highest in 2004, when 0.83 per cent of all NINo registrations were made by EaP nationals. This percentage has declined since then, falling to under 0.4 per cent in each year since 2007. More than half of NINo registrations from EaP countries in each year were made by Ukrainian nationals. This percentage was highest in 2002, at just over 62 per cent, and lowest in 2009, when Ukrainians accounted for 51.7 per cent of NINo registrations from EaP countries.

The latest Population Census took place in the UK in March 2011. However, not all data have been released for the different parts of the $\mathrm{UK}^{6}$. The most recent Census information on country of birth for the whole of the UK relates to 2001 and this tends to be aggregated, apart from large countries ${ }^{7}$. For example, information on the stock of foreign-born residents from Eastern European countries has been grouped into a single category, apart from Poland. Therefore, in order to obtain estimates of people born in countries with a small resident population in the UK in 2001, it is necessary to commission a table from the relevant national statistical agencies. However, in the 
country of birth database produced by OECD (2008), the resident population in the UK in 2001 is based on Census returns in different parts of the country. This information is presented in Table 4 and indicates that individuals born in the Ukraine accounted for 78 per cent of the total number of immigrants from EaP countries residing in the UK in 2001. However, people born in EaP countries only accounted for a very small percentage of not just the total population of the UK (less than 0.03 per cent) but also the immigrant population (0.31 per cent). Furthermore, Ukrainians only accounted for 0.24 per cent) of the UK immigrant population in 2001. The equivalent percentage for those born in all other EaP countries was just 0.07 per cent. Apart from Ukraine, the only other EaP country that had a resident population in excess of a 1,000 was Belarus-twice the number for the four remaining EaP countries.

According to the 2011 Census for England and Wales, there has been an increase in resident migrants from all six EaP countries. The estimated number of people born in Ukraine living in England and Wales in March 2011 was 20,700. This represents a fairly large increase in the stock of migrants over the 2001 figure for the UK as a whole (under 12,000), as shown in Table 5. Similarly, the estimated number of migrants from other EaP countries living in England and Wales had also risen quite substantially, and stood at 14,438 in 2011 (1,638 from Armenia, 2,641 from Azerbaijan, 4,133 from Belarus, 3,015 from Georgia and 3,011 from Moldova). However, migrants from all EaP countries still only accounted for $0.47 \%$ of all migrants in England and Wales in 2011.

Despite the relatively large inflows from some EaP countries in the mid-2000s highlighted in Figures 1 and 2, the relatively small estimated populations from EaP countries in the UK suggest that a high proportion of the migrant workers have subsequently left. This is certainly likely to be true of workers who were employed on the SAWS and SBS. There are only a few studies on return migration from the UK. Dustmann and Weiss (2007) use the LFS to examine return migration for a composite group of immigrants to the UK but their sample only covers the period 1992-2002. Pollard et al. (2008) estimate that perhaps half of post-enlargement EUA8 migrants had returned to their home countries between 2004 and 2007. This may provide some indication of the propensity for return migration amongst people from EaP countries, although EUA8 migrants are able to come to back to the UK to work without restriction, which is not the case for migrants from EaP countries.

Table 4 UK Resident population, immigrants and people born in EaP countries, 2001

\begin{tabular}{lcc}
\hline & Number & \% of all immigrants \\
\hline Armenia & 589 & 0.01 \\
Azerbaijan & 561 & 0.01 \\
Belarus & 1,154 & 0.02 \\
Georgia & 551 & 0.01 \\
Moldova & 455 & 0.01 \\
Ukraine & 11,913 & 0.24 \\
All EaP countries & 15,223 & 0.31 \\
Total immigrants & $4,896,600$ & 100.00 \\
Resident population & $58,820,242$ & - \\
\hline
\end{tabular}

Source: Census of Population, ONS. 
Table 5 Gender and broad age of migrants from EaP countries in the UK (in per cent)

\begin{tabular}{lcccc}
\hline & Male & Working age & N & Total migrants from EaP countries \\
\hline Ukraine & 51.4 & 56.6 & 362 & 72.7 \\
Belarus & 46.2 & 82.1 & 39 & 7.8 \\
Moldova & 50.0 & 92.9 & 28 & 5.6 \\
Armenia/Azerbaijan/Georgia & 49.3 & 78.3 & 69 & 13.9 \\
All EaP Migrants & 50.6 & 63.7 & 498 & 100.0
\end{tabular}

Source: LFS (1999-2011).

There are few reliable estimates of the number of illegal immigrants in the United Kingdom. However, the size of this group is likely to have increased over the last decade. For example, Gordon et al. (2009) provide a central estimate of 618,000 illegal immigrants in the United Kingdom in 2007. This compares with a central estimate of 430,000 by Woodbridge (2005) for 2001. There is some uncertainty around these estimates, with Gordon et al. (2009) suggesting that the true figure for 2007 is likely to lie somewhere between 417,000 and 863,000. Furthermore, neither study provides a breakdown of their estimates by country of origin, but the majority of illegal immigrants are estimated to be failed asylum seekers rather than overstayers or illegal entrants (Gordon et al. 2009). Failed asylum seekers originate from a wide range of countries, especially the Middle East, Sub-Saharan Africa, South Asia and Eastern Europe, whereas overstayers are typically from Asia and Africa (Gordon et al. 2009). This suggests that the total number of illegal immigrants from EaP countries in the United Kingdom is also likely to be very small, especially in comparison to the total population of legal immigrants, which is estimated to be around 8 million according to the recently published figures from the 2011 Census.

\section{Demographic characteristics of migrants from EaP countries to the UK}

This section is based on the analysis of data from the Quarterly LFS. The dataset used to examine the demographic characteristics of migrants from EaP countries resident in the UK has been constructed by merging (52) successive quarters of LFS data. In particular, information from the first quarter of 1999 has been combined with files up to the fourth quarter of 2011. This has been done because of the small number of observations in any one quarter, and identifiers for migrants from all EaP countries have only been included in the LFS from the start of 1999. Migrants from EaP countries have been defined according to their country of birth. To prevent double-counting, only those respondents in their first wave of interview are included in the dataset ${ }^{8}$. Drinkwater et al. (2009) contains further details on using the pooled LFS data to examine the demographic characteristics of immigrants from groups of countries. Given sample sizes, there is a need to combine the EaP countries together (with Ukraine and other $\mathrm{EaP}$ countries the most disaggregated split that is generally possible). Comparisons are made with other European migrants

In order to initially examine the characteristics in the sample of migrants from EaP countries, Table 5 contains information on just gender and age, the latter just split according to whether the individual is of working age. The table shows that a slight 
majority of migrants from EaP countries in the sample are male. There are some differences between countries, with this percentage varying from 46.2 per cent amongst Belarusian migrants to 51.4 per cent for migrants born in the Ukraine. However, the total number of observations in the sample for migrants from Belarus is small. The table also reveals the relatively high percentage of Ukrainian migrants who are not of working age since only around 57 per cent of this group are aged between 16 and 59 for women and 16 and 64 for men ${ }^{9}$. In contrast, over 80 per cent of non-Ukrainian migrants from EaP countries in the sample are of working age. The reason why a relatively low percentage of Ukrainian migrants are of working age is because 36 per cent of this group are aged 65 or over. This is consistent with the high percentage arriving in the UK before 1990 (37 per cent, compared with 5 per cent of migrants from other EaP countries).

The remaining discussion on the demographic characteristics of migrants from EAP countries is based on Table 6. This contains information on working age migrants from European countries to the UK from the pooled sample of LFS datafiles outlined above. These descriptive statistics relate to the observations that are used in the regression models that are estimated in the next section. Given the small number of observations of working age migrants from individual EaP countries, migrants from these countries have been combined into a single group. Clark and Drinkwater (2013) provide some further disaggregation of this group by reporting labour market and demographic characteristics of Ukrainians and migrants from other EaP countries to

Table 6 Demographic characteristics of working age migrants from EaP countries and comparison groups

\begin{tabular}{|c|c|c|c|c|}
\hline & $\mathrm{EaP}$ & EUA8 & EU14 & Other europe \\
\hline Female & 0.627 & 0.532 & 0.533 & 0.515 \\
\hline Age 16-24 & 0.129 & 0.189 & 0.081 & 0.090 \\
\hline Age 25-34 & 0.446 & 0.511 & 0.277 & 0.287 \\
\hline Age $35-49$ & 0.349 & 0.217 & 0.375 & 0.426 \\
\hline Age 50-64 & 0.076 & 0.083 & 0.268 & 0.196 \\
\hline Married & 0.671 & 0.500 & 0.573 & 0.702 \\
\hline Low education & 0.249 & 0.169 & 0.451 & 0.460 \\
\hline Medium education & 0.169 & 0.468 & 0.228 & 0.253 \\
\hline High education & 0.582 & 0.364 & 0.321 & 0.287 \\
\hline London & 0.442 & 0.245 & 0.267 & 0.457 \\
\hline South & 0.277 & 0.279 & 0.349 & 0.283 \\
\hline Midlands & 0.068 & 0.154 & 0.107 & 0.085 \\
\hline North & 0.141 & 0.178 & 0.147 & 0.112 \\
\hline Devolved regions & 0.072 & 0.145 & 0.131 & 0.062 \\
\hline Arrived before 1990 & 0.020 & 0.066 & 0.599 & 0.459 \\
\hline Arrived in 1990s & 0.402 & 0.100 & 0.233 & 0.294 \\
\hline Arrived 2000-3 & 0.341 & 0.126 & 0.094 & 0.132 \\
\hline Arrived 2004-7 & 0.185 & 0.614 & 0.060 & 0.082 \\
\hline Arrived 2008-11 & 0.052 & 0.094 & 0.015 & 0.033 \\
\hline$N$ & 249 & 5586 & 14399 & 5209 \\
\hline
\end{tabular}


the UK using a slightly larger number of observations. Information is also provided on three other groups of European migrants of working age: those born in the EUA8, EU14 and Other Europe for comparative purposes ${ }^{10}$.

Table 6 indicates that the information on gender in the LFS accord with the NINo database, which shows that recent migration flows from EaP countries have been dominated by women, since over 60 per cent of working-age migrants from EaP countries are female The age distribution of working-age migrants from EaP countries is more similar to that of EUA8 migrants than to migrants from other parts of Europe living in the UK. For example, around 8 per cent of working-age migrants from EaP countries and EUA8 are aged over 50 compared to over a quarter of EU14 migrants and 20 per cent from other parts of Europe. However, EUA8 migrants tend to be even more concentrated within the younger age categories than migrants from EaP countries due to the large inflows of EUA8 migrants that have arrived in the UK since 2004. Therefore, many of the differences in the age distribution will be strongly affected by the arrival patterns of the migrant groups.

Table 6 also confirms that the majority of migrants from EaP countries and the EUA8 are relatively recent arrivals. In particular, only a low percentage of migrants from EaP countries ( 2 per cent) and the EUA8 ( 7 per cent) arrived in the UK before 1990, compared to 60 per cent of migrants from EU14 and 46 per cent from other European countries. The bulk of migrants from EaP countries in the sample entered the UK between the early 1990s and mid-2000s, with 40 per cent arriving in the 1990s and 34 per cent between 2000 and 2003. This pattern of arrival is consistent with the decline in the inflows of migrants from EaP countries since the introduction of new migration policies in the second half of the 2000s. The heavy concentration of EUA8 migrants arriving between 2004 and 2007 is clearly visible, which also reveals that arrivals slowed after recession hit the UK.

The percentage from each group that are observed in particular educational categories is also reported in Table 6. These categories have been constructed from the variable indicating the age that the individual left full-time education, which is available in the LFS. This variable is used because of the difficulty in examining educational qualifications for migrants, since a large proportion would have obtained these in their home countries and so there may not be an equivalent qualification in the host country. As a result, the highest qualification for a high percentage of immigrants in the LFS is "Other". Three main educational categories are defined: low education (left full-time education before the age of 18); medium education (left between the ages of 18 and 20); and high education (left after the age of 20). Similar educational categories have been used by other studies of immigrants in the UK (see Dustmann et al. 2008). The percentage of migrants with high levels of education is also highest for migrants from EaP countries. There is, however, also a relatively high percentage of this group in the low education category in comparison to EUA8 migrants. The relatively high levels of education displayed by migrants from EaP countries and the EUA8 will be related to age, since younger and more recent migrants tend to be better educated. In addition, this may be partly due to different legal frameworks for migration from European countries, since there is now freedom of movement from the EUA8, as well as from the EU14, whereas migration from outside the European Union is likely to be more skill-biased. 
Finally, Table 6 indicates that around two-thirds of working-age migrants from EaP countries in the sample are married, which is slightly below the figure for Other European migrants but greater than that observed for migrants from the EU. The geographical location of migrants from EaP countries is similar to that of migrants from other European countries, with just under $45 \%$ of migrants from this group residing in London and $28 \%$ in the South of England. In contrast, migrants from the EU have a more dispersed location pattern, including a relatively high percentage living in Scotland, Wales and Northern Ireland.

\section{Labour market outcomes of European migrants in the UK}

In this section, the same LFS dataset is used to examine the labour market outcomes of migrants from EaP countries and these are again compared with the groups of European migrants that were introduced in the previous section. Table 7 provides some general statistics on labour market outcomes by reporting broad economic activity for each of the groups. The employment rate is higher for migrants from EaP countries (63 per cent) than it is for other European migrants but is much lower than those observed for migrants from the EU, especially from the EUA8. The employment rate differentials are further investigated using regression analysis later in this section.

Unemployment is also relatively high amongst migrants from EaP countries, with an unemployment rate (expressed as a percentage of economically active people) of almost 13 per cent. The unemployment rate is less than 6 per cent for migrants from the European Union and 8.3 per cent for other European migrants. The economic inactivity rate is also relatively high for migrants from EaP countries but is lower than for migrants from other European countries. This is particularly the case for women, since the economic inactivity rate for is around 30 per cent compared to $44 \%$ for female migrants from other European countries. Drinkwater and Robinson (2011) find that a relatively high percentage of migrants from other European countries (including people born in EaP countries) claim benefits in the UK, especially in comparison to people born in the EUA8 and EU14. This is true for both men and women, with relatively high levels of income support and sickness/disability claims observed for both sexes. This could be the result of higher levels of discouraged workers following job displacement, whilst the relatively low percentage of benefit claimants amongst EUA8 migrants is likely to have been influenced by the restrictions on access to benefits in the UK by this group following EU enlargement. Drinkwater and Robinson (2011) report that whilst social assistance claims initially increase with years since migration they do so at a decreasing rate and there is a varying impact for different migrant groups in the UK. The

Table 7 Economic activity of working-age migrants from EaP countries and comparison groups (in per cent)

\begin{tabular}{lcccc}
\hline & EaP & EUA8 & EU14 & Other Europe \\
\hline Employed & 63.1 & 78.8 & 72.1 & 59.6 \\
Unemployed & 9.2 & 4.9 & 4.3 & 5.4 \\
Inactive & 27.8 & 16.3 & 23.6 & 34.9 \\
$\mathrm{~N}$ & 317 & 6,254 & 16,457 & 6,135 \\
\hline
\end{tabular}

Source: LFS (1999-2011). 
turning point for the effect of years since migration on social assistance claims is highest for EU14 migrants (29 years in the UK) and amongst the lowest for Other European migrants (9 years in the UK). This is likely to reflect a higher incidence of social assistance claims due to ageing for EU14 migrants, whilst for Other Europeans it may reflect a different mix of origin countries across migrant cohorts.

In order to further examine employment outcomes, probit models have been estimated for each of the four groups of European migrants, with the results presented in Table 8. The dependent variable takes a value of 1 if the individual is employed and 0 otherwise, with full-time students excluded from the analysis. Controls have been included for gender, age, marital status, cohort of arrival, education and region. There are several common features in terms of the determinants of employment for the four migrant groups including significantly higher employment rates for males and more highly qualified individuals. The probability of employment is lowest amongst the 16-24 age group but the differences are not statistically significant for migrants from EaP countries, which may partly be the result of a relatively small number of observations. Neither is the dummy variable indicating whether the individual is married significantly different from zero for migrants from EaP countries. European migrants living in London tend to have a lower probability of employment compared to those residing in other parts of the UK, although the estimates are more mixed for migrants from EaP countries. The signs on the cohort of arrival dummies are also different for migrants from EaP countries, with those arriving prior to 1990 least likely to be employed.

Table 8 Probit estimates for the probability of employment for working-age migrants from EaP countries and comparison groups

\begin{tabular}{|c|c|c|c|c|c|c|c|c|}
\hline & \multicolumn{2}{|c|}{ EaP } & \multicolumn{2}{|c|}{ EUA8 } & \multicolumn{2}{|c|}{ EU14 } & \multicolumn{2}{|c|}{ Other Europe } \\
\hline & M.E. & $\overline{\text { S.E. }}$ & M.E. & $\overline{\text { S.E. }}$ & M.E. & $\overline{\text { S.E. }}$ & M.E. & S.E. \\
\hline Female & $-0.212^{* * *}$ & 0.057 & $-0.148^{* * *}$ & 0.010 & $-0.120^{* * *}$ & 0.007 & $-0.220^{* * *}$ & 0.013 \\
\hline Age $25-34$ & 0.028 & 0.143 & 0.000 & 0.023 & $0.075^{* * *}$ & 0.012 & $0.059^{* *}$ & 0.029 \\
\hline Age $35-49$ & 0.019 & 0.123 & $0.067^{* * *}$ & 0.020 & $0.106^{* * *}$ & 0.009 & $0.132^{* * *}$ & 0.021 \\
\hline Age 50-64 & 0.051 & 0.123 & $0.045^{* *}$ & 0.018 & $0.108^{* * *}$ & 0.008 & $0.162^{* * *}$ & 0.019 \\
\hline Married & -0.023 & 0.074 & $-0.083^{* * *}$ & 0.011 & $0.023^{* * *}$ & 0.008 & $-0.044^{* * *}$ & 0.016 \\
\hline Low Ed. & $-0.207^{* * *}$ & 0.082 & $-0.139^{* * *}$ & 0.019 & $-0.170^{* * *}$ & 0.009 & $-0.287^{* * *}$ & 0.017 \\
\hline Medium Ed. & $-0.170^{*}$ & 0.098 & $-0.024^{* *}$ & 0.012 & $-0.083^{* * *}$ & 0.011 & $-0.117^{* * *}$ & 0.021 \\
\hline South & 0.080 & 0.074 & $0.063^{* * *}$ & 0.012 & $0.061^{* * *}$ & 0.009 & $0.174^{* * *}$ & 0.015 \\
\hline Midlands & -0.086 & 0.139 & 0.024 & 0.016 & $0.039^{* * *}$ & 0.012 & $0.136^{* * *}$ & 0.021 \\
\hline North & 0.087 & 0.086 & 0.009 & 0.015 & 0.014 & 0.011 & $0.117^{* * *}$ & 0.020 \\
\hline Devolved regions & -0.047 & 0.136 & $0.066^{* * *}$ & 0.014 & -0.003 & 0.012 & $0.135^{* * *}$ & 0.024 \\
\hline Arrived in 1990s & 0.263 & 0.210 & $-0.084^{* * *}$ & 0.031 & $-0.028^{* * *}$ & 0.010 & $-0.213^{* * *}$ & 0.019 \\
\hline Arrived 2000-3 & 0.172 & 0.212 & 0.018 & 0.024 & -0.014 & 0.014 & $-0.195^{* * *}$ & 0.026 \\
\hline Arrived 2004-7 & $0.358^{* * *}$ & 0.101 & $0.038^{*}$ & 0.023 & $-0.030^{*}$ & 0.017 & $-0.077^{* * *}$ & 0.031 \\
\hline Arrived 2008-11 & 0.063 & 0.240 & -0.039 & 0.030 & $-0.120^{* * *}$ & 0.035 & $-0.133^{* * *}$ & 0.048 \\
\hline$N$ & \multicolumn{2}{|c|}{249} & \multicolumn{2}{|c|}{5586} & \multicolumn{2}{|c|}{14399} & \multicolumn{2}{|c|}{5209} \\
\hline
\end{tabular}

Notes: Table reports marginal effects based on sample means and standard errors. ${ }^{* * *} p<0.01,{ }^{* *} p<0.05,{ }^{*} p<0.1$. Full-time students have been excluded. Reference categories are aged 16-24, high education, lives in London and arrived in the UK before 1990. 
Table 9 Probit decomposition of the probability of employment for working-age migrants from EaP countries versus comparison groups

\begin{tabular}{lccc}
\hline & EUA8 & EU14 & Other Europe \\
\hline Mean differential in employment probability & -0.131 & -0.086 & 0.035 \\
Characteristics effect & $-0.076^{* * *}$ & $0.026^{* * *}$ & -0.001 \\
& $(0.013)$ & $(0.008)$ & $(0.013)$ \\
Coefficients effect & $-0.055^{* *}$ & $-0.112^{* * *}$ & 0.037 \\
& $(0.028)$ & $(0.030)$ & $(0.028)$ \\
\hline
\end{tabular}

Notes: Bootstrapped standard errors (200 replications) in parentheses. ${ }^{* * *} p<0.01,{ }^{* *} p<0.05,{ }^{*} p<0.1$.

Table 9 provides additional information on differences in employment outcomes between these groups by reporting the results from some probit decompositions (Gomulka and Stern 1990). This technique allows the mean differential in employment probabilities between migrants from EaP countries and those from other groups to be decomposed into components that can be explained by the explanatory variables that have been included in the model and that is unexplained by those characteristics and which may reflect differences in how the labour market rewards those characteristics or differences in motivation or other unobservable characteristics of the migrants. The results indicate that the majority of the differential between migrants from EaP and EUA8 countries is attributable to differences in (employment enhancing) characteristics: particularly cohort of arrival, region, gender and marital status. In contrast, there are only small characteristic effects between migrants from EaP countries and from EU14 and other European countries. However, the decompositions indicate that different effects appear to be at work here. In particular, the more favourable rewards that EU14 migrants receive for their characteristics far outweigh their disadvantage in relation to (employment enhancing) characteristics. In contrast, although other European migrants have similar characteristics, these are less well rewarded and this accounts for the higher employment rate observed for migrants from EaP countries. However the differences in characteristics and coefficients between EaP migrants and other Europeans are not found to be statistically significant in the decomposition which may suggest that these two groups of workers are closer substitutes in the production process.

Details on the occupational attainment of European migrants in the UK are provided in Table 10. EUA8 workers are highly concentrated within low-skilled occupations, with professional and managerial occupations accounting for less than 10 per cent of employment within this group. The occupational distribution is more evenly balanced for the other migrant groups. However, the percentage of EaP migrants working in the UK who are employed in professional and managerial positions is lower than for

Table 10 Occupation of working-age migrants from EaP countries and comparison groups (in per cent)

\begin{tabular}{lcccc}
\hline & EaP countries & EUA8 & EU14 & Other Europe \\
\hline Professional/Managerial & 27.3 & 9.4 & 35.4 & 30.0 \\
Intermediate occupations & 30.8 & 25.1 & 33.5 & 33.8 \\
Low-Skilled occupations & 41.9 & 65.5 & 31.2 & 36.2 \\
$\mathrm{~N}$ & 198 & 4893 & 11636 & 3594 \\
\hline
\end{tabular}

Source: LFS (1999-2011). 
migrants from EU14 and other European countries. Furthermore, over $40 \%$ of migrant workers from EaP countries in the sample are employed in low-skilled occupations. This is high, especially given the relatively large proportion who are highly qualified, but still far lower than the equivalent percentage observed for EUA8 migrants.

Information on the sector of employment is presented for each of the migrant groups in Table 11. This table again reveals some differences between migrants from EaP countries and the other groups, especially in relation to EUA8 migrants. In particular, there is a noticeably high incidence of employment amongst EUA8 migrants in the production, manufacturing, retail and hospitality, with a relatively low percentage (13 per cent) employed in business services and finance. In contrast, over a quarter of migrant workers from EaP countries are employed in this sector. This consists of two sections (financial intermediation and real estate, renting and business activities), spanning a total of eight industrial divisions, as detailed in the notes to Table 11. This is a relatively high paying sector, with gross average hourly earnings being over 40 per cent higher than the average earnings of European migrants in the sample of LFS data being examined. The comparatively high proportion of migrants from EaP countries employed in Business Services/Finance is consistent with their relative clustering in London-the UK's dominant financial centre. A relatively high proportion of migrants from EaP, EUA8 and Other European countries are also employed in retail and hospitality. Although public services account for 16 per cent of employment for migrant workers from EaP countries, this is relatively low in comparison to migrants from EU14 and other European countries.

The relatively low concentration of migrant workers from EaP countries in public services is confirmed by the statistics reported in the bottom row of the table, which show the percentage employed in the public sector. This is highest for EU14 migrants, followed fairly closely by migrants from other European countries. Only 11 per cent of migrants from EaP countries are employed in the public sector, although this is over 4 percentage points higher than the equivalent figure for EUA8 migrants. The percentage of migrants from EaP countries in

Table 11 Sector of employment for working-age migrants from EaP countries and comparison groups (in per cent)

\begin{tabular}{lcccc}
\hline & EaP countries & EUA8 & EU14 & Other Europe \\
\hline Production/Manufacturing & 13.0 & 26.5 & 14.3 & 12.1 \\
Construction & 9.5 & 9.2 & 6.0 & 9.1 \\
Retail/Hospitality & 26.5 & 25.7 & 19.7 & 25.3 \\
Transport/Communications & 3.5 & 8.6 & 6.4 & 6.4 \\
Business Services/Finance & 25.5 & 12.6 & 19.3 & 17.8 \\
Public services & 16.0 & 11.5 & 27.8 & 22.9 \\
Other services & 6.0 & 6.1 & 6.4 & 6.5 \\
Public sector & 11.0 & 6.6 & 22.1 & 18.4 \\
N & 200 & 5,238 & 1,2580 & 3,992 \\
\hline
\end{tabular}

Source: LFS (1999-2011).

Notes: Business Services/Finance consists of the following industrial divisions: financial intermediation, excluding insurance and pensions funding; insurance and pension funding, except compulsory social security; activities auxiliary to financial intermediation; real estate activities; renting of machinery and equipment without operator and of personal and household goods; computer and related activities; research \& development; and other business services. 
production and manufacturing is also relatively low, especially in comparison to EUA8 migrants. Further examination of this category indicates that only a relatively small percentage of the sample of workers from EaP countries is employed in agriculture. The proportion observed in production and manufacturing will, however, be influenced by the absence of some migrant workers from these sectors from the LFS sampling frame because of the higher incidence of short term and irregular employment, implying that the actual percentage of EaP migrants employed in these sectors is likely to be higher.

\section{Conclusions}

The analysis of various data sources above suggests that both the stocks and flows of migrants from EaP countries are relatively small in comparison to other migrant groups in the UK and that, while stocks have grown between Censuses, the flows have declined in recent years in response both to the economic situation and the tightening of immigration rules. EaP migrants share some of the characteristics of the much larger group of EUA8 migrants who have arrived in the UK since 2004, for example in terms of their age structure, years since migration and geographic location in the UK however they are more likely than EUA8 migrants to be have both high and low levels of educational qualifications. Their employment rates are poorer and they experience higher levels of unemployment and in activity than one would expect given their characteristics. Furthermore, in terms of how the UK labour market transforms their human capital and demographic characteristics into employment and occupational attainment, they appear to be more like workers from the Other European group rather than EUA8 or EU14 workers.

The EU's Eastern Partnership strategy views the nations discussed in this paper as an important group with whom increased integration yields the possibility of mutual economic benefit and enhanced political association (European Commission 2012). A longer term objective of this strategy is to support the mobility of EaP nationals hence the extent to which labour market integration with the UK is possible for EaP countries has formed the background to our study. The overwhelming conclusion must be that there is little prospect for future large-scale EaP migration to the UK. As noted earlier, numbers have declined as immigration rules have become more restrictive and, while the UK economy is now recovering following the financial crisis, the regression results reported in Table 3 suggest that even a sustained period of positive economic growth is unlikely to increase migration flows by a substantial amount.

The only potential caveat to this relates to the fact that a high proportion of EaP migrants are relatively well qualified. The switch to the PBS has focused attention in the UK on the types of high skilled migrants that the country needs to fill strategic skills gaps. STEM qualifications have been noted as a key area (Clarke 2011; George et al. 2012) and there is some evidence that the EaP countries may represent a source of STEM-qualified workers. UNESCO provides estimates of the subject of graduation of university graduates for a variety of countries and the data suggest that both Ukraine and Belarus have amongst the highest proportions of graduates in the world in the areas of "science, engineering, manufacturing and construction"11. As a proportion of 
all graduates $26 \%$ in Ukraine and $27 \%$ in Belarus are in those areas, comparing favourably with $27 \%$ in Germany, $22 \%$ in the UK and $15 \%$ in the US. The figure for Poland, the major source of EUA8 migrants in the 2000s, is also 15\%, whilst for Bulgaria it is $19 \%$.

However there seems little prospect that in the short to medium term the climate in the UK is likely to become more open to large scale migration flows given how hostile to immigration public attitudes remain. This is in spite of evidence suggesting that there is little (negative) impact on the labour market (Dustmann and Fabbri 2005; Blanchflower et al. 2007; Lemos and Portes 2008), whilst there can be very positive effects on public finances (Gott and Johnston 2002; Dustmann et al. 2010) and on economic growth (Borjas 1995; Drinkwater et al. 2007). Opinion polls regularly show that over $70 \%$ of the population support reduced migration and the issue of migration has steadily become more important for people as net migration has increased since $2000^{12}$. This headline finding does, however, obscure some subtleties around the public's attitudes towards migrants. Ford (2011), for example, finds that there is a "hierarchy of preferences" with immigrants of the same colour and with a similar culture preferred to those who are non-white and more culturally distinct. However Ford's data are from a period before large scale migration from EUA8 countries. Similarly, skilled migrants and those whom it is believed will come to the UK to contribute to the economy or to fill skill gaps are favoured over the unskilled (Ford et al. 2012). More recent evidence suggests that migrants from Eastern Europe are less welcome than those from Western Europe, the Old Commonwealth (Canada, Australia and New Zealand) and the United States. Eastern Europeans were favoured to a similar extent as those from Latin America, Asia or Africa ${ }^{13}$. Overall, this does not suggest that there would be much support from either politicians or the public for a relaxation of immigration restrictions for EaP nationals.

\section{Endnotes}

${ }^{1}$ NINo registrations should provide a relative accurate indication of the number of migrant workers coming to work in the UK for the first time since they are obtained from an administrative database maintained by the Department for Work and Pensions. Further information on this data source is provided in Flows of migrants from EaP Countries to the UK and migrant stocks.

${ }^{2}$ In contrast, the percentage of NINo registrations accounted for by individuals from Asia and the Middle East fell from 32 per cent to 20 per cent over the same period, whilst the percentage of registrations accounted for by Africans declined from 19 per cent to 8 per cent.

${ }^{3}$ EUA8 migrant workers were required to register on the Worker Registration Scheme within one month of taking up employment in the UK. However, it is estimated that a fairly high percentage of workers who should have registered failed to do so. See Drinkwater et al. (2009) for details. Much tighter restrictions were put in place for Bulgarian and Romanian migrants wishing to work in the UK, after these countries joined the European Union in 2007.

${ }^{4}$ In 2007, the overall quota for the SAWS was 16,250. Of this amount, 40 per cent was reserved for Bulgarians and Romanians and the remaining 60 per cent was filled by students from non-EEA countries. The SAWS and SBS became reserved just for 
workers from Bulgaria and Romania from January 2008. Salt (2009) reports that there were a small number of workers from Ukraine (61) and Moldova (9) on the SAWS in 2008. This compared with 10,850 Bulgarians and 5,674 Romanians in that year.

${ }^{5}$ These figures are consistent with those reported for the SAWS and SBS by Salt (2009).

${ }^{6}$ Different national statistical agencies carry out the Census in England and Wales, Scotland and Northern Ireland. This sometimes means some variations in the questions asked and also the need to aggregate responses together to obtain figures for the United Kingdom.

${ }^{7}$ In particular, Table ST015 contains details on country of birth (for countries with larger resident populations in the United Kingdom), and also enables a limited breakdown by characteristics for gender, age group and area of residence.

${ }^{8}$ For 1999 , however, respondents in their fifth wave of interview are also included, which provides a slight boost to the sample.

${ }^{9}$ More detailed information on age differences is included in Table 6.

${ }^{10}$ The EU14 countries are Austria, Belgium, Denmark, Finland, France, Germany, Greece, Ireland, Italy, Luxembourg, Netherlands, Portugal, Spain and Sweden. Other European Countries are those countries in Europe that are not part of the EU14, EUA8 or the EaP so includes countries such as Bulgaria, Romania and Croatia, which joined the EU after 2004.

${ }^{11}$ Data tables are available at the UNESCO statistics website: http://www.uis.unesco. org/Pages/default.aspx. Calculations are the authors'.

${ }^{12}$ See the summary by the Migration Observatory: http://www.migrationobservatory.ox.ac.uk/briefings/uk-public-opinion-toward-immigration-overall-attitudes-andlevel-concern.

${ }^{13}$ See the analysis reported by one of the present authors at http://blog.policy.manchester.ac.uk/featured/2013/10/what-kind-of-immigration-do-we-want/.

\section{Additional file}

Additional file 1: Table S1. Passengers given leave to enter the UK from EaP Countries, 2004-10. Table S2. Passengers given leave to enter the UK from EaP countries by route, 609 2004-10.

Competing interests

The IZA Journal of European Labor Studies is committed to the IZA Guiding Principles of Research Integrity. The authors declare that they have observed these principles.

\section{Acknowledgements}

This study was conducted under the project entitled "Costs and Benefits of Labour Mobility between the EU and the Eastern Partnership Countries" for the European Commission (Contract No. 2011/270-312, tender procedure EuropeAid/130215/C/SER/Multi). The European Commission retains ownership of the materials contained herein. Material from the Quarterly Labour Force Survey is Crown Copyright and has been made available by the Office for National Statistics (ONS) through the Economic and Social Data Service. We are also grateful to comments on an earlier draft from Martin Kahanec and Lucia Kurekova. The views expressed in this study and any errors therein are those of the authors.

Responsible editor: Martin Kahanec

Author details

${ }^{1}$ IZA \& University of Manchester, Manchester, UK. ${ }^{2}$ IZA \& Swansea University, Swansea, UK. 
References

Blanchflower D, Bell D (2010) "UK unemployment in the Great Recession", National Institute Economic Review, pp R3-R25

Blanchflower D, Saleheen J, Shadforth C (2007) "The impact of recent migration from Eastern Europe on the UK economy". IZA Discussion Paper No. 2615, Bonn

Blinder S (2011) UK public opinion toward immigration: Overall attitudes and level of concern. University of Oxford, Migration Observatory Briefing Paper, Oxford

Borjas GJ (1995) The economic benefits from immigration. J Econ Perspect 9(2):3-22

Clark K, Drinkwater S (1998) Ethnicity and self-employment in Britain. Oxf Bull Econ Stat 60:393-407

Clark K, Drinkwater S (2013) "UK migration policy and migration from Eastern Partnership Countries". IZA Discussion Paper No. 7665, Bonn

Clarke S (2011) "The STEM subject push", Civitas Online Report. http://www.civitas.org.uk/pdf/stempush2011.pdf

Devitt C (2012) "Labour migration governance in contemporary Europe. The UK case", Fieri Working Paper

Drinkwater S, Levine P, Lotti E, Pearlman J (2007) The immigration surplus revisited in a general equilibrium model with endogenous growth. J Reg Sci 47:569-601

Drinkwater S, Eade J, Garapich M (2009) Poles apart? EU enlargement and the labour market outcomes of immigrants in the UK. Int Migr 47:161-190

Drinkwater S, Eade J, Garapich M (2010) "What's behind the figures? An investigation into recent Polish migration to the UK". In: Black R, Engbersen G, Okolski M, Pantiru C (ed) A Continent Moving West? EU Enlargement and Labour Migration from Central and Eastern Europe. Amsterdam University Press, Amsterdam

Drinkwater S, Robinson C (2011) "Welfare participation by immigrants in the UK". IZA Discussion Paper No. 6144, Bonn

Dustmann C, Fabbri F, Preston I (2005) The impact of immigration on the British labour market. Econ J 115:F324-F341

Dustmann C, Frattini T, Hills C (2010) Assessing the fiscal costs and benefits of A8 migration to the UK. Fisc Stud 31:1-41

Dustmann C, Glitz A, Frattini T (2008) The labour market effects of immigration. Oxf Rev Econ Policy 24:478-495

Dustmann C, Weiss Y (2007) Return migration: theory and empirical evidence from the UK. Br J Ind Relat 45:236-256

European Commission (2012) "EU cooperation for a successful Eastern Partnership". Available at: http://ec.europa.eu/ europeaid/where/neighbourhood/eastern_partnership/documents/eastern_partnership_flyer_final_en.pdf

Ford R (2011) Acceptable and unacceptable immigrants: how opposition to immigration in Britain is affected by migrants' region of origin. J Ethn Migr Stud 37:1017-1037

Ford R, Morrell G, Heath A (2012) Fewer but better? Public views about immigration. In: Park A, Clery E, Curtice J, Phillips M, Utting D (ed) British Social Attitudes: The 29th Report. NatCen Social Research, London

George A, Lalani M, Mason G, Rolfe H, Rosazza Bondibene C (2012) Skilled immigration and strategically important skills in the UK economy. Report to the Migration Advisory Committee, London

Gomulka J, Stern N (1990) The employment of married women in the United Kingdom 1970-83. Economica 57:171-199

Gordon I, Scanlon K, Travers T, Whitehead C (2009) "Economic impact on the London and UK economy of an earned regularisation of irregular migrants to the UK". Report to the Greater London Authority, London

Gott C, Johnston K (2002) The migrant population in the UK: Fiscal effects. Home Office Research, Development and Statistics Occasional Paper No. 77, London

Gregg P, Wadsworth J (2010) Employment in the 2008-2009 recession. Econ Labour Market Rev 4(8):37-43

Hatton T (2005) Explaining trends in UK immigration. J Popul Econ 18:719-740

Hatton T, Wheatley Price S (2005) Migration, migrants and policy in the United Kingdom. In: Zimmermann KF (ed) European Migration: What Do We Know? Oxford University Press, Oxford

Lemos S, Portes J (2008) "The impact of migration from the new European Union member states on native workers". Department for Work and Pensions Working Paper No. 52, London

OECD (2008) Country of Birth Database, Organisation for Economic Cooperation and Development

ONS (2012) Employment Levels by Country of Birth and Nationality. Office for National Statistics, London

Pollard N, Latorre M, Sriskandarajah D (2008) Floodgates or Turnstiles? Post EU Enlargement Migration Flows to (and from) the UK. Institute for Public Policy Research, London

Salt J (2009) International migration and the United Kingdom. Report of the United Kingdom SOPEMI Correspondent to the OECD, London

Woodbridge J (2005) Sizing the unauthorised (illegal) migrant population in the United Kingdom in 2001", Home Office Online Report 29/05

10.1186/2193-9012-3-15

Cite this article as: Clark and Drinkwater: Labour migration to the UK from Eastern partnership countries. IZA

Journal of European Labor Studies 2014, 3:15 